\title{
A Study on the Development Aspect by Year through Smart City Trend Cases
}

\author{
HwiYeong Jeong ${ }^{1}$, Ri Ryu ${ }^{2}$ and YongSeong Kim ${ }^{3}$ \\ ${ }^{1,2,3}$ Graduate School of Techno Design, Kookmin University \\ 1dhssk00@naver.com, ${ }^{2}$ ri23414@hanmail.net, ${ }^{3}$ yongkim@kookmin.ac.kr
}

\begin{abstract}
The population that currently resides in cities throughout the world accounts for more than 50\% of world's population due to rapid global urbanization since the 19th century, causing many serious urban problems, including lack of residential facilities and urban infrastructure, traffic congestion and environmental destruction. Due to continuous advancement of communication technologies since the 20th century, the world trend of industrial technologies encountered a turning point from the 3rd industrial revolution to the 4th industrial revolution. As results of such periodic transitions, the smart city, which is intended to solve urban issues intelligently, has appeared. At the same time, smart technologies, such as ICT, IoT, Big Data, and data-crowding, all of which are considered technologies of the 4th industrial revolution, are being integrated with the urban infrastructure. In this study, the standards for unique smart city components were set by as follows. First, the cases regarding the overseas trend of the smart city appearing after the 2000s by year were classified. Second, precedent studies regarding the smart city were analyzed. Then, the development aspects of the smart city were considered and studied by analyzing the trend cases of the smart city accordingly. The purpose of this study is to recognize that the smart city is an alternative city for today and the future and to establish fundamental research data for understanding the smart city.
\end{abstract}

Keywords: Smart City, ICT, IoT, Big Data, data-crowding, City Component

\section{Introduction}

\subsection{Background and Purpose of Study}

The world population is currently 7.6 billion and it is expected to reach approximately 8.6 billion in 2030 and approximately 9.8 billion in 2050. Currently, approximately half of the total population lives in cities, and it is predicted that over $60 \%$ of the total population will live in cities in 2030. Since cities have failed to meet the requirements of the population that is living in their limited areas, various urban problems have occurred, posing serious implications. Major urban problems that must be solved include the deterioration and lack of urban infrastructure, lack of housing facilities, congested traffic, lack of green, and the destruction of the environment due to increased carbon dioxide emissions. Many people in the world are being harmed both directly and indirectly from natural disasters, such as abnormal climate and fine dust, which occurs every year due to increased carbon dioxide emissions, which contribute to the destruction of the environment. The investment and development of a sustainable city model that can effectively manage various urban problems resulting from rapid urbanization are being made actively throughout the world. Moreover, multidirectional discussions are being held in order to manage the growth of rapidly changing cities and promote quality development efficiently. As the understanding and definition of the 4th industrial

Received (November 26, 2017), Review Result (January 26, 2018), Accepted (February 2, 2018) 
revolution were discussed officially at the Davos Forum held on January 2016, smart technologies such as IoT, artificial intelligence, 3D printers, and CPS Big Data have changed the paradigm in all fields throughout the world in the 21st century. Such aspects were applied and integrated with the urban management and infrastructure. Consequently, the new term, "Smart City," was created. The scientific development represented as the 4th industrial revolution has penetrated deep into the industry as well as the society and culture. A new world paradigm has combined and applied with solutions for the urban problems mentioned earlier, changing the form of city-related content, such as new city management, infrastructure service, and lifestyle.

In this study, the objective is to recognize that the smart city is an alternative model of a city that solves urban problems intelligently and provides a new platform of intelligent urban management and conduct a fundamental analysis for a smart city. The cases of trends of overseas smart cities appearing after the 2000s are classified by year and the detailed analysis is conducted according to the newly set standards of smart city components. Furthermore, the direction of future development will be considered by analyzing the development aspect of the smart city by year according to the analysis result.

\subsection{Range and Method of Study}

In this study, the concept, definition, and background of the smart city are considered by analyzing and summarizing precedent domestic and overseas literature regarding smart city that were retrieved. The target city is selected based on city governments that officially select the smart city as the representative of urban policies and update research and results of government projects as the national project after the 2000s.

The selected target cities are classified by year and the characteristics of the selected target cities are analyzed based on the smart city component analysis method suggested in this study. Lastly, the characteristics of the development aspect of the smart city are identified and comprehensive analysis results are drawn from the analysis contents.

Table 1. Scope and Method of Analysis

\begin{tabular}{|l|l|}
\hline \multicolumn{1}{|c|}{ Range of Study } & \multicolumn{1}{c|}{ Method of Study } \\
\hline & $\begin{array}{l}\text { - Draw the result of the diachronic } \\
\text { development aspect of the smart city and } \\
\text { the possibility in future }\end{array}$ \\
$\begin{array}{l}\text { - Analyze the established form of overseas } \\
\text { - Assess concept and appearance } \\
\text { background of the smart city }\end{array}$ & $\begin{array}{l}\text { - Identify the trend of the smart city } \\
\text { - Detailed classification according to the } \\
\text { classification of smart cities by year and } \\
\text { components }\end{array}$ \\
\hline
\end{tabular}

\section{Consideration of Smart City Theory}

\subsection{Definition of Smart City}

Various concepts of the smart city are defined and used, including various variables such as the application fields, purpose and form of development, and the user. The smart city is based on the premise of information communication technology for the optimization of service and governance system for city operation, electrical grid type, public transportation, education, and lifestyle. However, the actual implementation varies according to the urban infrastructure, history, and citizenship where the technology is practiced. Therefore, it is very difficult to establish a clear definition of the smart city. It is 
true that the concept of the smart city is being newly defined and used continuously both at home and abroad.

According to 'A Study on Setting up the Concept of the Smart City through Analysis on the Term 'Smart" (Choi, 2011), the smart city is a city where the infrastructure for telecommunication is connected akin to the neural computer of humans. In this regard, the network between members of the city is prepared perfectly due to the development of computer technologies in the smart city as a new type of city in the 21 st century, as predicted by futurologists. This study explains the smart city as a new type of city where the traffic network is established akin to the spider's web.

The term "Smart City" has been used practically and academically since the 20th century, but it was already mentioned in a similar concept in the late 1900s. The efficient management and operation of a city using IT technologies by introducing the ICT technologies to the urban infrastructure and systems for regulatory effects have been developed under various names, such as 'wired cities' (Dutton et al., 1987), 'cyber cities' (Graham and Marvin 1999), 'digital cities' (Ishda and Isbister 2000), 'intelligent cities' (Kominow 2002), 'smart city' (Holland 2008), or 'sentiment cities' (Shepard 2011).

In this way, there are various interpretations and opinions available, but the definition of the concept of the smart city is still unclear. The boundary between the use of the term in other fields is also unclear, leaving room for many interpretations.

\subsection{Background of Smart City}

Various interpretations regarding the appearance of the smart city have been presented in previous literature. In terms of urban development, the word "smart" in Smart City was used first from "Smart Growth," which was a type of urban development that was introduced as a solution for the sprawl issue due to the low-density development of the suburbs in the U.S. in the late 1980s. Here, 'Smart' growth was used as the concept of development to accept the growth according to decision-making process through mutual cooperation while continuing economic growth without destroying the environment. Efficient and horizontal development and management or maintenance of sustainable resources to solve existing problems were considered as smart methods. This also carries a similar concept with the basic concept of "smart" in the smart city currently used. In the IT market after the global financial crisis in 2008, IBM, a major global enterprise, used a city as a testbed for the investment target of ICT technologies and developed the first smart city. Such an experimental endeavor was also later confirmed by several EU cities. Large cities in EU that faced various urban problems due to rapid urbanization began to apply the smart education and smart industry approaches to the existing city. Eco-friendly smart homes and smart lifestyles using ICT and IoT information communication technologies were provided to citizens of the smart city. Therefore, the smart city emphasizing the reinforcement of innovative technologies and investment on ICT services under the slogan "Improvement of Quality of Public Service and Life" was officially discussed at 'Europe's Digital Agenda' in 2010 and its application has begun in EU. The market where the application of the smart city and studies are being conducted most actively until now are cities in European countries. The smart city is being used continuously as a sustainable future-oriented smart city platform.

\section{Analysis of Development Aspect of the Smart City}

\subsection{Analysis Methodology of Smart City Components According to the Development Aspect of the Smart City}

In this study, the smart city was considered an alternative city model to efficiently solve and manage current or near future urban problems by using smart technologies, such as IoT, ICT, and data-crowding effectively. Globally renowned smart cities 
designated by local governments after the 2000s that were cited academically were selected and studied. Domestic and overseas precedent studies were analyzed in order to set the framework of new city components for the smart city. In the 'European Smart Cities 4.0' study by TUWIEN University 'Smart City' was classified as a city that thoroughly carried out 6 dimensions. The components of the smart city were classified into Smart Economy, Smart Mobility, Smart Environment, Smart People, Smart Living, and Smart Governance.

Table 2. 'European Smart Cities 4.0,' Detailed Smart Components

\begin{tabular}{|c|c|c|c|c|c|c|}
\hline $\begin{array}{l}\text { Smart } \\
\text { Compon } \\
\text { ents }\end{array}$ & $\begin{array}{l}\text { Smart } \\
\text { Economy }\end{array}$ & $\begin{array}{l}\text { Smart } \\
\text { Governance }\end{array}$ & Smart Living & $\begin{array}{l}\text { Smart } \\
\text { People }\end{array}$ & $\begin{array}{l}\text { Smart } \\
\text { Environm } \\
\text { ent }\end{array}$ & Smart Mobility \\
\hline $\begin{array}{l}\text { Detailed } \\
\text { Items }\end{array}$ & $\begin{array}{l}\text {-Innovative } \\
\text { spirit } \\
\text { Entrepreneur } \\
\text { ship } \\
\text {-City image } \\
\text {-Productivity } \\
\text {-Labor } \\
\text { Market } \\
\text { - } \\
\text { International } \\
\text { integration }\end{array}$ & $\begin{array}{l}\text {-Political } \\
\text { awareness } \\
\text {-Public and } \\
\text { social } \\
\text { services } \\
\text {-Efficient } \\
\text { and } \\
\text { transparent } \\
\text { administratio } \\
\text { n }\end{array}$ & $\begin{array}{l}\text {-Cultural and } \\
\text { leisure facilities } \\
\text {-Health conditions } \\
\text {-Individual } \\
\text { security } \\
\text {-Housing quality } \\
\text {-Education } \\
\text { facilities } \\
\text { - Touristic } \\
\text { attractiveness } \\
\text {-Social cohesion }\end{array}$ & $\begin{array}{l}\text {-Education } \\
\text {-Lifelong } \\
\text { learning } \\
\text {-Ethnic } \\
\text { plurality } \\
\text {-Open- } \\
\text { mindednes } \\
\text { s }\end{array}$ & $\begin{array}{l}\text {-Air } \\
\text { quality (no } \\
\text { pollution) } \\
\text { - } \\
\text { Ecological } \\
\text { awareness } \\
- \\
\text { Sustainabl } \\
\text { e resource } \\
\text { manageme } \\
\text { nt }\end{array}$ & $\begin{array}{l}\text {-Local transport } \\
\text { system } \\
\text {-(Inter)national } \\
\text { accessibility } \\
\text {-ICT- } \\
\text { Infrastructure } \\
\text {-Sustainability } \\
\text { of the transport } \\
\text { system }\end{array}$ \\
\hline
\end{tabular}

Also, according to "A Study on Planning Methodologies for Smart City Master Plan" (Kim, Kwon, Yang, Huh, 2015), the establishment direction of smart service and infrastructure according to the spatial characteristics for a designated site was presented. In the field of smart service, a new standard for the smart city master plan was set by applying 5 classification items including "Business", "Education", "Culture \& Tourism", "Home \& Building", and "Health \& Welfare" with 17 detailed service items.

Table 3. Detailed Smart Services

\begin{tabular}{|c|c|c|c|c|c|}
\hline $\begin{array}{l}\text { Smart } \\
\text { Services }\end{array}$ & Business & Education & $\begin{array}{l}\text { Culture \& } \\
\text { Tourism }\end{array}$ & $\begin{array}{l}\text { Home \& } \\
\text { Building }\end{array}$ & $\begin{array}{l}\text { Health \& } \\
\text { Welfare }\end{array}$ \\
\hline $\begin{array}{l}\text { Detailed } \\
\text { items }\end{array}$ & $\begin{array}{l}\text {-Smart } \\
\text { work } \\
\text {-Web } \\
\text { conference } \\
\text {-Intelligent } \\
\text { office }\end{array}$ & $\begin{array}{l}\text {-Remote } \\
\text { education } \\
\text {-Smart } \\
\text { campus } \\
\text {-Smart } \\
\text { library }\end{array}$ & $\begin{array}{l}\text {-Information \& } \\
\text { experience } \\
\text {-Smart park } \\
\text {-Concierge } \\
\text { service } \\
\text {-Smart sports }\end{array}$ & $\begin{array}{l}\text {-Home } \\
\text { management } \\
\text {-Home } \\
\text { entertainment } \\
\text {-Building energy } \\
\text { management } \\
\text { system }\end{array}$ & $\begin{array}{l}\text {-Remote } \\
\text { healthcare } \\
\text {-Smart } \\
\text { hospital } \\
\text {-Family } \\
\text { healthcare }\end{array}$ \\
\hline
\end{tabular}

The purpose of 'European Smart Cities 4.0' examined earlier is to establish a convenient city by applying smart technologies to an existing city. This is the standard method for the implementation of service and infrastructure technologies and smart lifestyle for an existing city. Therefore, there are limitations in using such a standard throughout societies of other cities due to different urban composition characteristics.

The frame of the standard regarding the smart city plan suggested in "A Study on Planning Methodologies for Smart City Master Plan" is the customized standard for the master plan of a certain city. It was determined that the same standard cannot be applied 
to the analysis method of other cities with different form, components, and characteristics.

The analysis framework that could be used in the cases of different forms, components, and characteristics of other cities, as well as the society, was re-established and proposed by supplementing the problems based on the two precedent studies mentioned earlier.

The components of the smart city suggested in this study are classified into five components. These components are classified into detailed items, including smart governance and smart welfare in the field of society, balanced development, eco-friendly resource and energy use in the field of industry, revival of urban economy and selfsufficient regional economy in the field of economy, smart transportation and smart education in the field of environment and community, smart communication, and SNS in the field of culture.

Table 4. Renewal Components of Smart City

\begin{tabular}{|c|c|c|}
\hline Field & Components of City & Planned Goal \\
\hline \multirow[t]{2}{*}{ Society } & Smart governance & $\begin{array}{l}\text { Continuous exchange of communication with and } \\
\text { feedback from citizens (not a one-sided government } \\
\text { administration) }\end{array}$ \\
\hline & Smart welfare & $\begin{array}{c}\text { Provision of customized services and facilities for } \\
\text { residents of various classes }\end{array}$ \\
\hline \multirow[t]{2}{*}{ Industry } & Balanced development & $\begin{array}{l}\text { Promotion of balance between phased development } \\
\text { and conservation and top-down development }\end{array}$ \\
\hline & $\begin{array}{l}\text { Eco-friendly resource } \\
\text { and energy }\end{array}$ & Efforts to establish eco-friendly city \\
\hline \multirow[t]{2}{*}{ Economy } & $\begin{array}{l}\text { Revival of urban } \\
\text { economy }\end{array}$ & $\begin{array}{l}\text { Revitalization of local economic through the } \\
\text { marketing of the smart city and a new occupational } \\
\text { cluster corresponding to the 4th industrial technology }\end{array}$ \\
\hline & $\begin{array}{l}\text { Self-sufficient regional } \\
\text { economy }\end{array}$ & $\begin{array}{l}\text { Establishment of self-sufficient and stable urban } \\
\text { economy }\end{array}$ \\
\hline \multirow[t]{2}{*}{ Environment } & Smart transportation & $\begin{array}{l}\text { Establishment of green transportation network and } \\
\text { smart management of traffic flow }\end{array}$ \\
\hline & Smart education & $\begin{array}{c}\text { Implementation of educational environment regardless } \\
\text { of location }\end{array}$ \\
\hline \multirow[t]{2}{*}{ Culture } & Smart community & $\begin{array}{l}\text { Efforts to provide and revitalize the place of } \\
\text { community enabling active communication in real- } \\
\text { time }\end{array}$ \\
\hline & $\begin{array}{l}\text { Smart communication } \\
\text { and SNS }\end{array}$ & $\begin{array}{l}\text { Establishment of safe network enabling active } \\
\text { communication in real-time }\end{array}$ \\
\hline
\end{tabular}

\subsection{Analysis of Development Aspect of Smart City by Year}

Smart cities that appeared in the 21st century were set as target cities and classified through the classification analysis method according to diachronic development. The selected smart cities were analyzed based on the subdivided components of the aforementioned city. The overall establishment form and subdivided components of the smart city are analyzed and the findings will be utilized as basic data for the development of a guideline that is necessary for the establishment of smart cities in the future. 
Table 5. Diachronic Development Aspect of the Smart City

\begin{tabular}{|c|c|c|}
\hline Target City & Outline of City & Form of Smart City Composition \\
\hline $\begin{array}{l}\text { Barcelona, Spain } \\
2001 \sim\end{array}$ & $\begin{array}{l}\text { Area: } 101.9 \mathrm{~km}^{2} \\
\text { Population: } 1.609 \text { million }\end{array}$ & $\begin{array}{l}\text { - Establishment of smart city management system } \\
\text { using the smart city strategy application 'City OS' } \\
\text { - Establishment of smart infrastructure, such as } \\
\text { irrigation system, using sensor technology, traffic } \\
\text { flow, and signal management system for data analysis } \\
\text { - Renewable and effective energy management and } \\
\text { green building (solar water heater, green building } \\
\text { renovation) } \\
\text { - Promotion of transparent city management led by } \\
\text { citizens with public database }\end{array}$ \\
\hline $\begin{array}{l}\text { Cape Town, } \\
\text { South Africa } \\
2002 \sim\end{array}$ & $\begin{array}{l}\text { Area: } 400.28 \mathrm{~km}^{2} \\
\text { Population:433,688 }\end{array}$ & $\begin{array}{l}\text { - Efforts to establish smart city platform for local } \\
\text { governments as well as the whole country } \\
\text { - Establishment of safe smart social network using ICT } \\
\text { (reduce the crime rate, eliminate AIDS, create jobs, } \\
\text { and establish the travel guidance service network) } \\
\text { - IT service education - local governments, authorities }\end{array}$ \\
\hline $\begin{array}{l}\text { Boston, USA } \\
2015 \sim\end{array}$ & $\begin{array}{l}\text { Area:124 km² } \\
\text { Population:673,184 }\end{array}$ & $\begin{array}{l}\text { - Smart administration and management: public } \\
\text { security and safety, smart building, city management, } \\
\text { government and agency management } \\
\text { - Smart infrastructure: Management of water, } \\
\text { transportation and organizations } \\
\text { - Smart life: Social program, healthcare, education }\end{array}$ \\
\hline $\begin{array}{l}\text { Kuala Lumpur, } \\
\text { Malaysia } \\
2016 \text { }\end{array}$ & $\begin{array}{l}\text { Area: } 243 \mathrm{~km}^{2} \\
\text { Population: } 1.589 \text { million }\end{array}$ & $\begin{array}{l}\text { - Smart economy: Smart economic policies for } \\
\text { innovative economic growth and equitable distribution } \\
\text { of wealth } \\
\text { - Smart administration: Open administration service } \\
\text { between the government and citizens using data } \\
\text { security } \\
\text { - Smart environment: Promote the growth of green } \\
\text { economy using green smart technologies } \\
\text { - Smart movement: Install the transit hub and expand } \\
\text { urban ITC infrastructure } \\
\text { - Smart citizen: Promote the growth of closer } \\
\text { community } \\
\text { - Smart life: IoT-based platform - Convenient city life }\end{array}$ \\
\hline $\begin{array}{l}\text { Hangzhou, } \\
\text { China } \\
2016 \sim\end{array}$ & $\begin{array}{l}\text { Area: } 16,847 \mathrm{~km}^{2} \\
\text { Population:9.188 million }\end{array}$ & $\begin{array}{l}\text { - Hangzhou on Palm: The largest public shared bike } \\
\text { rental system in the world } \\
\text { - AI hub (Hangzhou City Brain): Manage the traffic } \\
\text { flow using big data center working with Alibaba } \\
\text { Group } \\
\text { - Smart transportation management system: Overall } \\
\text { transportation network of Hangzhou is managed so } \\
\text { that the average vehicle speed has increased by } 11 \% \\
\text { compared to the past. } \\
\text { - Hangzhou Resident Card: } 13 \text { E-SERVICE related to } \\
\text { normal citizens' life. ATM use, bike rental, and } \\
\text { purchase of food can be handled by this card. }\end{array}$ \\
\hline
\end{tabular}




\begin{tabular}{|c|c|c|}
\hline $\begin{array}{l}\text { Stockholm, } \\
\text { Sweden } \\
\text { (1994, partially) } \\
2017 \sim\end{array}$ & $\begin{array}{l}\text { Area: } 188 \mathrm{~km}^{2} \\
\text { Population: } 942,370\end{array}$ & $\begin{array}{l}\text { - Establish the environmental program using Green-IT } \\
\text { technologies in various fields including traffic } \\
\text { network, land and water, garbage, building, and energy } \\
\text { - e-service: Establish effective public service network } \\
\text { using Internet to improve the quality of life for citizens } \\
\text { - Connect the computer network of the entire city } \\
\text { using fiberglass underground } \\
\text { - Investment on global ICT research cities }\end{array}$ \\
\hline
\end{tabular}

Table 6. Diachronic Development Aspect of the Smart City

\begin{tabular}{|c|c|c|c|c|c|c|c|c|c|c|}
\hline \multirow{3}{*}{ Target City } & \multicolumn{10}{|c|}{ Components of Smart City } \\
\hline & \multicolumn{2}{|c|}{ Society } & \multicolumn{2}{|c|}{ Industry } & \multicolumn{2}{|c|}{ Economy } & \multicolumn{2}{|c|}{ Environment } & \multicolumn{2}{|c|}{ Culture } \\
\hline & $\begin{array}{l}\text { Gover } \\
\text { nance }\end{array}$ & $\begin{array}{c}\text { Welfa } \\
\text { re }\end{array}$ & $\begin{array}{c}\text { Balance } \\
\text { d } \\
\text { develop } \\
\text { men }\end{array}$ & $\begin{array}{c}\text { Resou } \\
\text { rce } \\
\text { and } \\
\text { energy }\end{array}$ & $\begin{array}{c}\text { Reviva } \\
\text { l of } \\
\text { urban } \\
\text { econo } \\
\text { my }\end{array}$ & $\begin{array}{c}\text { self- } \\
\text { sufficie } \\
\text { nt } \\
\text { regiona } \\
\text { l } \\
\text { econom } \\
y\end{array}$ & $\begin{array}{c}\text { Smart } \\
\text { trans } \\
\text { portat } \\
\text { ion }\end{array}$ & $\begin{array}{c}\text { Smart } \\
\text { educa } \\
\text { tion }\end{array}$ & $\begin{array}{c}\text { Smar } \\
t \\
\text { com } \\
\text { muni } \\
\text { ty }\end{array}$ & $\begin{array}{c}\text { Com } \\
\text { muni } \\
\text { catio } \\
\text { n \& } \\
\text { SNS }\end{array}$ \\
\hline $\begin{array}{l}\text { Barcelona, } \\
\text { Spain } \\
2001 \text { }\end{array}$ & 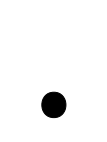 & $x$ & $x$ & $x$ & 0 & - & & $x$ & $\mathrm{x}$ & $x$ \\
\hline $\begin{array}{l}\text { Cape } \\
\text { Town, } \\
\text { South } \\
\text { Africa } \\
2002 \sim\end{array}$ & 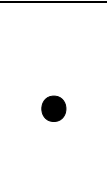 & O & 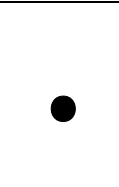 & $x$ & $x$ & ○ & 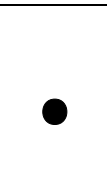 & $x$ & $x$ & $x$ \\
\hline $\begin{array}{c}\text { Boston, } \\
\text { USA } \\
2015 \sim\end{array}$ & 0 & $x$ & 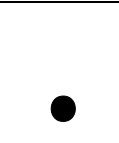 & $x$ & $x$ & 0 & 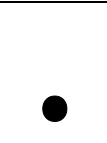 & 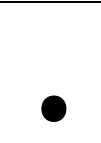 & $x$ & $x$ \\
\hline $\begin{array}{c}\text { Kuala } \\
\text { Lumpur, } \\
\text { Malaysia } \\
2016 \sim\end{array}$ & C & $x$ & 0 & $x$ & O & $x$ & 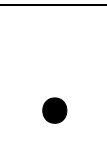 & 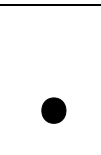 & 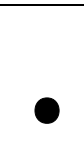 & \\
\hline $\begin{array}{c}\text { Hangzhou, } \\
\text { China } \\
2016 \sim\end{array}$ & $x$ & $x$ & O & ○ & 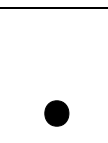 & ○ & 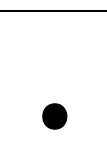 & 0 & 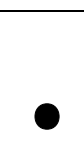 & 0 \\
\hline $\begin{array}{c}\text { Stockholm, } \\
\text { Sweden } \\
(1994, \\
\text { partially) } \\
2017 \sim \\
\end{array}$ & & 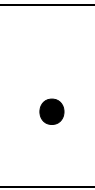 & 0 & 0 & 8 & 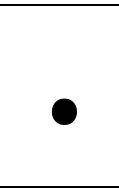 & & & & \\
\hline
\end{tabular}

The development aspect of the smart city since the 2000s can be summarized as follows.

\section{1) Framework for the Composition of the Smart City}

The framework for the composition of the smart city is divided into society, industry, economy, environment, and culture. The subordinate concepts include smart governance and smart welfare for society, balanced development, eco-friendly resource and energy 
use for industry, revival of urban economy, self-sufficient regional economy for economy, smart transportation and smart education for environment and smart community, and smart communication and SNS (Social Network Service) for culture.

First, the administration system enabling continuous communication and exchange of feedback with citizens, not the centralized system of government, is promoted by changing the local government into the smart local government that collects Big Data using IoT and ICT technologies and carries out its administration in terms of society.

Second, the smart grid and smart city industry for balanced development and ecofriendly resource and energy use are established in terms of the industrial aspect. This is to focus on phased development and conservation and to promote a horizontal and transparent relationship with corporations in terms of industry.

Third, a healthy smart city is established and relevant marketing is carried out in terms of the economic aspect to focus on the economy industry for the 4th industrial revolution in terms of the economy. Moreover, the revitalization of the local economy through new technologies which correspond to the 4th industrial technology and occupational cluster is promoted in order to complete a self-sufficient regional economy.

Fourth, it is intended to manage the overall traffic flow of the relevant city smoothly using IoT and ICT technologies. Another objective is to establish the educational environment regardless of the physical distance and location by expanding the smart transportation network and educational facilities in a balanced way in terms of environment.

Fifth, it has significance in the maintenance of bottom-up communication with government and a horizontal relationship with residents by establishing the place of the smart community and communication in terms of culture.

\section{2) Development Aspect of Smart City Components}

As a result of analyzing the development aspects of city components according to the diachronic classification of the smart city, social development, revival of urban economy, and resource and energy elements become more obvious. The purpose of the smart city in its early stage was to provide greater convenience in the lives of residents by applying smart technologies to infrastructure and service. However, we can expect its direction to manage the city in an efficient and smart way by applying and using smart technologies in the form of data clouding to the entire city. This can be achieved gradually for the social development, urban economy, and resource and energy.

\section{3) Shift of Authority from the Government to Citizens}

Top-down urban developments based on capital have been advanced considerably since the 20th century according to rapid urbanization. Nevertheless, components in the field of culture that enable communication network for continuous feedback led by citizens become more obvious as the form of urban development and management promoted by the smart city appeared after the 2000s, as shown in Table 3. It is shifted to the method that enables transparent administration under the continuous interest of citizens, rather than that of the ambiguous and one-sided government administration in the past. This shows that the backward supervision in the form of 'Synopticon' mentioned by Thomas Mathieson became available. Consequently, the investment for promoting a transparent society is currently in progress.

\section{4) Problems}

Because the whole city is hyper-connected by smart technologies, there is concern that the invasion of privacy may occur between the government and the individual, between individuals, and between an individual and an organization. The government's monitoring 
in the form of 'Panopticon' mentioned by Jeremy Bentham may appear paradoxically. Since the urban platform based on the data cloud where all the IoT data in the city is gathered into the center is used, it is true that it may have considerable side effects. Therefore, the establishment of a system that enables continuous feedback from citizens according to transparent and horizontal governance and appropriate government leadership is required.

\section{Conclusion}

Cities in the world face urgent urban problems that need to be solved in a smart way beyond physical and economic growth. Cities also have been changed in a smart way along with the trend of the 4th industrial revolution after the 2000s when the smart city began to appear. Successful application of smart technologies to cities throughout the world after the 2000s has been proven. As a result, large cities in the world are changing into smart cities.

Therefore, renowned cities regarded as smart cities were selected as the target cities. Those selected cities were classified by year in this study. The analysis method framework was reconfigured and the smart city components were analyzed in order to assess the development aspect of the smart city. The smart city components were classified into 5 fields, including society, industry, economy, environment, and culture. These 5 fields were subdivided into 10 subordinate concepts. According to the diachronic development aspect of smart components, the social development, revival of urban economy, and resource and energy elements in the smart city become more obvious as time passes. We can thus predict the direction of urban management for the smart city in the future. We can also identify the transition in which the authority of the city is shifted from the government to its citizens according to the ICT-based citizen-initiative network.

Moreover, large global corporations such as Google, IBM, and Huawei are investing in the technical development of the 4th industrial revolution. 'Arup', a global construction company estimated that global market for smart city will grow to 40 billion per year until 2020 for the smart city service. This company plans to establish 500 smart cities in China until 2030. Based on such evidence, we can expect that the smart city is assessed as highly favorably in present times and will be continuously developed and applied in the future.

\section{Acknowledgments}

This paper is a revised and expanded version of Preliminary Survey Study on Smart City Urban Components presented at HSST, December 2017.

\section{References}

[1] A. N. Sakar, "Smart Cities: A Futuristic Vision", (2017), pp. 1-15.

[2] K. Donyun, K. Wonsoon, Y. Sungmin and H. Hyosung, “A study on Planning Methodologies for Smart City Master Plan”, Urban Design Institutes of Korea, vol. 15, no. 5, (2015), pp. 110-122.

[3] D. Seungyoun, "Thinking about Smart city in the way of M. Foucault's 'Problematization'”, Korean Association of Space \& Environment Research, vol. 27, no. 1, (2017), pp. 15-38.

[4] T. Pablo, "Upgrading infrastructure as a path to become a Smart city", Actual Smart City, (2017), pp. 18.

[5] K. Klaus R, "Smart Cities: A New Paradigm of Urban Development”, CRIOS, (2014), pp. 9-19.

[6] G. Rudof and H. Gudrun, "Smart Cities Ranking: And Effective Instrument for the Positioning of Cities?", ACE: Architecture, City and Enviroment, vol. 4, no. 12, (2010), pp. 7-25.

[7] K. Minsuk and L. Woohyoung, "A study on Approach System of Creative City with the Consideration of Sustainable Urban Regeneration”, Journal of Digital Interaction Design, vol. 11, no. 1, (2012), pp. 59-72.

[8] N. Teawoo and P. Theresa A, "Smart City as Urban Innovation: Focusing on Management, Policy, and Context", (2011), pp. 185-194. 
[9] L. SamSu, "A Change of City paradigm and Importance", Korean Land \& Housing Corporation Research, (2006).

[10] A Santora, "The City: A Place of Places, Examining the Link Between Place, Architecutre and Humanity Within the Urban Fabric", (2014).

[11] K. Rob, "The Real-time City? Big data and smart urbanism", GeoJournal, vol. 79, no. 1-14, (2014).

[12] S. Kehua, L. Jie and F. Hongbo, "Smart City and the Applications", IEEE, (2011), pp. 1028-1031.

[13] L. Seong Hoon, "A Case Study on Foreign Smart City", Journal of Digital Convergence, vol. 12, no. 4, (2014), pp. 305-310.

[14] L. Si Yeong, L. Yong Min and L. Jae Yong, "Study on the Trends of U-City and Smart City Researches using Text Mining Technology", Journal of the Korean Society for Geospatial Information System, vol. 22, no. 3, (2014), pp. 87-97.

[15] C. Bong Moon, "A Study on Setting up the Concept of Smart City through Analysis on the Term 'Smart', International Journal of Contents, vol. 11, no. 12, (2011).

[16] J. Roozbeh, E. Khalil and M. Carolyn, "Smart City Architecture for Community Level Services Through the Internet of Things", Proceeding of the $18^{\text {th }}$ International Conference in Next Generation Networks, Paris, France, (2015) February 17-19. 